\title{
Development and Application of Real-Time and Conventional SSR-PCR Assays for Rapid and Sensitive Detection of Didymella pisi Associated with Ascochyta Blight of Dry Pea
}

\author{
Ayodeji Owati, Bright Agindotan, and Mary Burrows ${ }^{\dagger}$ \\ Department of Plant Sciences and Plant Pathology, Montana State University, Bozeman, MT 59717, U.S.A.
}

\begin{abstract}
Didymella pisi is the primary causal pathogen of Ascochyta blight (AB) of dry pea in Montana. Diagnosis of AB is challenging because there are six different species that cause $\mathrm{AB}$ worldwide and that can co-occur. Additionally, agar plate identification of $D$. pisi is challenging due to its slow growth rate. Currently, there are no PCR-based assays developed for specific detection of $D$. pisi or any fungal pathogen in the $\mathrm{AB}$ complex of dry pea. In this study, we evaluated simple sequence repeat (SSR) primer pairs for their specificity and sensitivity in real-time and conventional SSR-PCR both in vitro and in planta. The specificity of

To avoid false-negative results, plant and fungal DNA markers were included as controls in a conventional multiplex SSR-PCR, to amplify any plant or fungal DNA in the absence of the D. pisi SSR target. SYBR Green SSR-quantitative PCR (qPCR) detection was conducted using the same primer pairs but in a uniplex format. $D$. pisi was specifically amplified, whereas other fungi and host DNA were not. Also, sensitivity experiments showed that the detection limit was $0.01 \mathrm{ng}$ of DNA of D. pisi for both assays and 100 conidia in SSR-qPCR. These assays are valuable diagnostic tools for the detection of $D$. pisi.
\end{abstract} the assay was determined by testing DNA of 10 dry pea varieties, fungal species in the $\mathrm{AB}$ complex, and fungal species associated with dry pea.
Keywords: field crops, fungi, pathogen detection, techniques
In 2017, in total, 1 million acres of dry pea (Pisum sativum) were harvested in the United States, representing a farm-gate value of \$170 million (USDA-NASS 2017). In Montana during the 2017 cropping season, 190,200 ha of dry pea were harvested, representing a farmgate value of $\$ 42$ million. Also, Montana accounted for $47 \%$ of the total U.S. dry pea production in 2018 (USDA-NASS 2018). Changes in pathogen populations and the risk of moving pathogens to new areas pose a great risk to the production of high-quality and disease-free dry pea seed required in the export markets.

Six fungal species have been associated with Ascochyta blight (AB) of dry pea (Aveskamp et al. 2010; Barilli et al. 2016; Davidson et al. 2009; Li et al. 2011; Tran et al. 2014; Trivoli and Banniza 2007). All of these pathogens can exist together on a host or independently of each other (Davidson et al. 2009; Trivoli and Banniza 2007). However, Didymella pisi, Peyronellaea pinodes, and P. pinodella are the only three fungal pathogens associated with $\mathrm{AB}$ of dry pea in the Great Plains of North America. In Australia, Phoma koolunga, $P$. glomerata, and $P$. herbarum are the additional pathogens associated with the disease. (Aveskamp et al. 2010; Davidson et al. 2009; Li et al. 2011; Tran et al. 2014). These pathogens are associated with shrinking and discoloration of dry pea seed, and lesions on foliar parts of pea plants (Bretag and Ramsey 2001; Bretag et al. 2006; Gossen et al. 2011; Skoglund et al. 2011). In Montana, the predominant fungal species associated with $\mathrm{AB}$ of dry pea is D. pisi (Owati et al. 2017). D. pisi is seed and residue borne and the dry pea plants are susceptible to the pathogen at every growth stage (Davidson et al. 2009, 2011; Gossen et al. 2011). Under conditions favorable to the

\footnotetext{
${ }^{\dagger}$ Corresponding author: M. Burrows; mburrows@montana.edu
}

Funding: The study was funded by the Department of Plant Science and Plant Pathology, Montana State University, Regional Pulse Crop Diagnostic Laboratory, Bozeman, MT supported by USDA/Montana Farm Bill 16-8530-1769CA-FB Pulse Crop Lab.

The author(s) declare no conflict of interest.

Accepted for publication 7 June 2019.

(C) 2019 The American Phytopathological Society disease, the pathogen can cause 15 to $30 \%$ yield loss in dry pea (Ahmed et al. 2015; Wallen 1965; Xue et al. 1996, 1997).

Current identification methods for $D$. pisi are laborious and time consuming. Identification using an artificial medium such as potato dextrose agar requires between 9 and 12 days for the fungus to grow and sporulate (International Seed Testing Association 2017]; Owati et al. 2017). Furthermore, molecular identification of this pathogen is challenging because of the high sequence similarities of fingerprinting genes such as internal transcribed spacer (ITS) genes and intergenic sequences that exist among AB-associated pathogens. To date, the use of multiple gene sequences has been used to identify this pathogen (Liu et al. 2016). Confounding diagnostics further is the fact that the other two pathogens (Peyronellaea pinodes and $P$. pinodella) associated with $\mathrm{AB}$ of dry pea in the Great Plains of North America have symptom expression on pea plants similar to that of $D$. pisi. These challenges complicate diagnosis, reinforcing the need for an accurate and sensitive assay to diagnose this pathogen and track changes in pathogen populations over time.

For both initial and rapid evaluation of AB-diseased plant samples, the detection of $D$. pisi for diagnostic purposes in the field and laboratory have focused on the use of symptoms, the morphology of asexual structures (pycnidia), and sequencing of the fungus ITS region and other conserved genes. The use of artificial media is laborious and time consuming due to the slow-growing nature of D. pisi and the need for single-spore isolation to obtain pure cultures (Ahmed et al. 2015; Davidson et al. 2009). Multiloci gene sequencing used for the diagnosis of $D$. pisi is not rapid and requires pure cultures which might take 10 to 14 days for mycelial growth. An additional 3 to 5 days are needed for DNA isolation, PCR, and sequencing of amplicons (Liu et al. 2016). Thus, a rapid, sensitive, and specific pathogen detection method will facilitate pathogen identification and assist with more timely and effective disease management strategies such as tracking changes in pathogen populations and determining the need for targeted fungicide applications (Wang et al. 2006). Early detection of the fungal pathogen on plants will inform targeted fungicide application and, thus, control disease incidence.

Molecular biology techniques, including PCR, have been used widely for detection and identification of phytopathogenic fungal species. Both conventional and real-time PCR assays have been developed for both in vitro and in planta detection and quantification of 
a number of foliar, root, and soil phytopathogenic fungi (Bhat and Browne 2010; Bonants et al. 1997; Cao et al. 2007; Chilvers et al. 2007; Henson et al. 1993; Hughes et al. 1998; Hussain et al. 2005; Keller et al. 1995; Kuzdraliński et al. 2017; Li et al. 2013; Lin et al. 2009; Moricca et al. 1998; Moukhamedov et al. 1994; Niepold and Schöber-Butin 1995; Phan et al. 2002; Wang et al. 2006, 2007; Wang et al. 2015). Zitnick-Anderson et al. (2018) developed a multiplexed quantitative PCR (qPCR) for the identification and quantification of seven Fusarium spp. associated with root rot of dry pea. Also, Rojas et al. (2017) developed a qPCR and recombinant polymerase amplification assays for genus- and species-specific detection and quantification of Phytophthora sojae and P. sansomeana root rot pathogens of soybean from plant tissue and soil samples.

Currently, there is no rapid, sensitive, and specific detection assay developed for in vitro and in planta detection of any of the pathogens in the $\mathrm{AB}$ complex of dry pea. Moreover, this hinders diagnosis and epidemiological studies, because several closely related species can cause similar symptoms on dry pea plants. The objectives of this study were to (i) develop a specific, conventional simple sequence repeat (SSR)-PCR assay for the detection of D. pisi; (ii) develop an SSR-qPCR assay for specific detection and quantification of $D$. pisi; and (iii) validate the qPCR and PCR assays in the presence of both host materials and other fungal species.

\section{Materials and Methods}

Fungal isolates and DNA extraction. Fungal genera associated with $\mathrm{AB}$ of dry pea and other genera commonly associated with dry pea and used in this study, including Didymella, Peyronellaea, Phoma, Alternaria, Stemphylium, Nigospora, Fusarium, Botrytis, Colletotrichum, Sclerotinia, and Cladosporium, were collected from symptomatic dry pea leaves and seed from Montana, Idaho, and Washington. Phoma koolunga DNA was provided courtesy of Dr. Jenny Davidson, South Australia Research and Development Institute, Urrbrae, South Australia, Australia. Single-spore cultures of each isolate were maintained on potato dextrose agar (PDA) at $22^{\circ} \mathrm{C}$ with a 12 -h diurnal photoperiod. Total genomic DNA was extracted from 10-day-old cultures grown on PDA using the DNeasy Plant Mini Kit (Qiagen, Germantown, MD, U.S.A.), with modification of the starting process. Fresh fungal mycelium of each isolate (100 mg) from a 10-day-old culture was scraped into a 2-ml screwcap tube (MP Biomedicals, Santa Ana, CA, U.S.A.) containing $450 \mathrm{ml}$ of AP1 buffer. The mycelium was disrupted using the SPEX SamplePrep 2010 Geno/Grinder (SPEX SamplePrep LLC, Metuchen, NJ, U.S.A.) set at 1,500 rpm for $60 \mathrm{~s}$ and centrifuged at $13,000 \times \mathrm{g}$ for $1 \mathrm{~min}$. About $400 \mathrm{ml}$ of lysate was then transferred to a $1.5-\mathrm{ml}$ collection tube. From this stage onward, the protocol followed the manufacturer's instructions. The quality and concentration of extracted DNA were estimated using the NanoDrop 2000c Spectrophotometer at $260 \mathrm{~nm}$ (Thermo Fisher Scientific, Waltham, MA, U.S.A.). The DNA samples were stored at $-20^{\circ} \mathrm{C}$ until further use.

Development of conventional SSR-PCR for specific and sensitive detection of $\boldsymbol{D}$. pisi. Screening of SSR primers for D. pisi specificity. Nine SSR primer pairs (A311, A313, A315, A318, A321, A324, A325, A326, and A342) (Owati et al. 2019) which amplified a single band in 205 D. pisi isolates from Montana were selected for this study. These primers were screened for their specificity to D. pisi using host plant DNA and other fungal DNA templates in uniplex PCR. Total genomic DNA was extracted from the foliage of 10 widely planted dry pea varieties in Montana courtesy of Dr. Kevin McPhee of Montana State University, Bozeman, using a cetyltrimethylammonium bromide procedure (Abarshi et al. 2010) (Table 1).

The PCR was optimized in a total volume of $25 \mu$ l containing $12.5 \mu$ l of Dream Taq Green PCR $2 \times$ Master mix (Thermo Fisher Scientific), $10 \mathrm{pM}$ each forward and reverse primer, and $2.5 \mu \mathrm{l}$ of DNA (50 ng). Amplification parameters were $4 \mathrm{~min}$ at $94^{\circ} \mathrm{C}$, followed by 30 cycles of $30 \mathrm{~s}$ at $94^{\circ} \mathrm{C}$ and $30 \mathrm{~s}$ at $56.6^{\circ} \mathrm{C}$, and a final extension at $72^{\circ} \mathrm{C}$ for $5 \mathrm{~min}$ in a thermocycler (Bio-Rad iCycler; Bio-Rad Laboratories, Hercules, CA, U.S.A.). The PCR products were analyzed on SYBR Safe-stained $2.5 \%(\mathrm{wt} / \mathrm{vol})$ agarose gels run in a $1 \times$ sodium-borate buffer (Brody and Kern 2004) and exposed to blue light to visualize DNA fragments. The amplicon sizes were estimated using a 100-bp DNA ladder (Thermo Fisher Scientific) (Owati et al. 2019).

Conventional multiplex SSR-PCR for D. pisi detection. Only SSR primers pairs that did not amplify host DNA were used for further experiments (Table 2). Each of the four D. pisi-specific SSR primer pairs (A311-F/R, A313-F/R, A315-F/R, and A318-F/R) together with fungal ITS and Rubisco L-gene (RBCL) primer pairs (Table 2) were tested for compatibility in conventional multiplex detection of $D$. pisi. The ITS and RBCL primers were used to amplify fungal and host plant DNA internal control DNA targets, respectively. DNA was extracted from two fungal-infected dry pea leaf samples, pure cultures of four fungal species in the $\mathrm{AB}$ complex, and nine other fungal species of dry pea (Table 3) and used at $50 \mathrm{ng}$ for the PCR to test also for the specificity of the multiplex PCR. The PCR mix and cycling conditions were as described above, except $10 \mathrm{pM}$ each of the ITS and RBCL primers was added to amplify the internal controls (Nassuth et al. 2000; White et al. 1990).

Conventional multiplex SSR-PCR assay sensitivity tests. The sensitivity of the SSR-PCR assay was assessed by diluting DNA extracted from $D$. pisi culture. Genomic DNA of D. pisi $(100 \mathrm{ng} / \mu \mathrm{l})$ was serially diluted 10 -fold from $100 \mathrm{ng} / \mu \mathrm{l}$ to $10 \mathrm{fg} / \mu \mathrm{l}$. The diluted DNA was used as a template in a multiplex PCR as previously described with ITS primers to amplify the fungal internal control target. Furthermore, to determine the sensitivity of this assay in the presence of host DNA, D. pisi DNA was serially diluted 10-fold from $100 \mathrm{ng}$ to $10 \mathrm{fg}$ in $50 \mathrm{ng}$ of DNA from dry pea (cultivar Aragorn). Diluted DNA was used as a template in a multiplex PCR assay with $D$. pisi SSR, ITS, and RBCL primers to specifically amplify $D$. pisi, fungal ITS, and plant RBCL targets, respectively.

SYBR Green real-time SSR-PCR amplification parameters. SYBR Green qPCR amplifications were performed on the Bio-Rad CFX96 real-time PCR detection system (Bio-Rad Laboratories). The annealing temperature of the assay was optimized in a gradient qPCR. The SYBR Green real-time was optimized in a total volume of $20 \mu \mathrm{l} \mathrm{con-}$ taining $10 \mu \mathrm{l}$ of iTaq Universal SYBR Green Supermix (Bio-Rad Laboratories), $10 \mathrm{pM}$ each forward and reverse primer, and $2.5 \mu \mathrm{l}$ of DNA (50 ng). Amplification parameters were $4 \mathrm{~min}$ at $94^{\circ} \mathrm{C}$, followed by 30 cycles of $30 \mathrm{~s}$ at $94^{\circ} \mathrm{C}$ and $30 \mathrm{~s}$ at $59^{\circ} \mathrm{C}$, and a final extension at $72^{\circ} \mathrm{C}$ for $5 \mathrm{~min}$.

Specificity and sensitivity tests of the SYBR Green quantitative real-time SSR-PCR assay. Mycelial DNA. To determine the specificity of the real-time SSR-PCR assay, $50 \mathrm{ng}$ of mycelial genomic DNA each of the target and nontarget fungal species listed in Table 3 was used individually as a template. Primer pairs A311-F/R and $\mathrm{A} 315-\mathrm{F} / \mathrm{R}$ specific to $D$. pisi were evaluated in the validation stage. The quantification cycle $(\mathrm{Cq})$ values of the target and nontarget fungal species were estimated in a Bio-Rad CFX96 real-time PCR detection system (Bio-Rad Laboratories).

To determine the efficiency and sensitivity of the assays, a 10-fold D. pisi mycelial genomic DNA serial dilution from $100 \mathrm{ng}$ to $10 \mathrm{fg}$ was amplified using primer pair A311-F/R. Real-time qPCR efficiency was calculated with the formula efficiency $=\left(10^{(-1 / \mathrm{slope})}-\right.$ $1) \times 100$. The slope was calculated from the linear regression between DNA $\log _{10}$ (template DNA concentrations) and $\mathrm{Cq}$ values using the Bio-Rad CFX Manager software package (Bio-Rad Laboratories).

A similar experiment was conducted to determine the detection limit of the real-time qPCR assay in the presence of host plant leaf DNA using primer pair A311-F/R. Mycelial genomic DNA from D. pisi was serially diluted 10 -fold from $100 \mathrm{ng}$ to $1 \mathrm{fg}$ in $50 \mathrm{ng}$ of genomic DNA from pea leaf (cultivar Aragorn). The Cq values were estimated as previously described.

Conidial DNA. In order to quantify the number of spores that could be detected in an assay, a conidial suspension was obtained from three 15-day-old cultures of D. pisi. This experiment was conducted twice. To prepare the suspension, the petri plate was flooded with $10 \mathrm{ml}$ of sterile distilled water and conidia were dislodged using a sterile glass rod. The conidial count was estimated 
using a hemocytometer viewed with a phase contrast Leica TCS SP5 imaging system (Leica Microsystems Inc., Buffalo Grove, IL, U.S.A.). The spore concentration was adjusted to $10^{5}$ conidia/ml and serially diluted 10 -fold to 10 conidia/ml. DNA was extracted from each spore concentration using the DNeasy Plant Mini Kit (Qiagen) according to the manufacturer's instructions, with modification of the starting process, and tested with the specific qPCR assays. The efficiency and slope of the assay were computed as previously described.

Validation of the SYBR Green real-time PCR assay. To validate these assays, genomic mycelial DNA of 30 isolates of $D$. pisi (Table 4) isolated from $\mathrm{AB}$ symptomatic dry pea seed and plants from Montana were spiked with genomic DNA of dry pea at $20 \mathrm{ng}$ of D. pisi $+50 \mathrm{ng}$ of host plant DNA per 20- $\mu$ l PCR. Two replicates of each isolate were used in this experiment. The samples were tested using the PCR assays according to the methods previously described.

Data analyses. Real-time PCR results were collected and analyzed, and qPCR standard curve plots and DNA concentration correlations were plotted, using the Bio-Rad CFX Manager software package (Bio-Rad Laboratories). The results are presented below.

\section{Results}

Specificity and sensitivity of conventional PCR assay. Of the nine SSR primer pairs screened with host pea DNA (data not shown), only four primer pairs (A311-F/R, A313-F/R, A315-F/R, and A318F/R) (Table 2) did not amplify host DNA of 10 dry pea varieties (Table 1; Figs. 1 and 2) and nontarget fungal pathogens associated with dry pea but specifically amplified and detected $D$. pisi isolates (Table 3). In addition, internal control templates were amplified in the multiplex PCR detection of D. pisi with RBCL primers (642bp product) and ITS (550-bp product) primers when the host plant and nontarget fungal were present, indicating that the primers were compatible with SSR primers in the multiplex PCR (Fig. 3). The detection limit of $D$. pisi in the conventional multiplex PCR in both the

Table 1. List of dry pea varieties used in the specificity test of the Didymella pisi markers

\begin{tabular}{|c|c|c|}
\hline \multirow[b]{2}{*}{ Dry pea variety } & \multicolumn{2}{|c|}{ PCR amplification using } \\
\hline & D. pisi-specific markers & Rubisco $L$-gene markers \\
\hline Hyline & - & + \\
\hline Treasure & - & + \\
\hline CDC Leroy & - & + \\
\hline Banner & - & + \\
\hline Aragorn & - & + \\
\hline Ginny & - & + \\
\hline Montech 4193 & - & + \\
\hline MSGA-Jet Set & - & + \\
\hline Early Star & - & + \\
\hline Nette 2010 & - & + \\
\hline
\end{tabular}

presence and absence of host DNA was $0.01 \mathrm{ng}$ of $D$. pisi DNA (Fig. 4).

Specificity and sensitivity of the SYBR Green real-time SSRPCR assay. The SYBR Green PCR assay was specific and sensitive for the detection of $D$. pisi in the presence of the DNA of both the dry pea host and other fungal species. The qPCR detected all $D$. pisi

Table 3. Specificity test panel for conventional multiplex polymerase chain reaction assay

\begin{tabular}{|c|c|c|c|}
\hline \multirow[b]{2}{*}{ Fungi species, isolate ID } & \multicolumn{2}{|c|}{ Amplification $^{\mathbf{a}}$} & \multirow[b]{2}{*}{ Origin } \\
\hline & PCR & ITS & \\
\hline Alternaria alternata, 15 & - & + & Montana \\
\hline A. alternata, 44 & - & + & Montana \\
\hline A. alternata, 49 & - & + & Montana \\
\hline Botrytis cinerea, 2 & - & + & Montana \\
\hline B. cinerea, 3 & - & + & Montana \\
\hline B. cinerea, 4 & - & + & Montana \\
\hline Cladosporium sp., 84 & - & + & Montana \\
\hline Colletotrichum lentis, 63 & - & + & Montana \\
\hline C. lentis, 74 & - & + & Montana \\
\hline C. lentis, 80 & - & + & Montana \\
\hline Didymella pisi, 01-12 & + & + & Montana \\
\hline D. pisi, 01-13 & + & + & Montana \\
\hline D. pisi, 01-14 & + & + & Montana \\
\hline D. pisi, $01-15$ & + & + & Montana \\
\hline Fusarium avenaceum, 6 & - & + & Montana \\
\hline F. avenaceum, 13 & - & + & Montana \\
\hline F. avenaceum, 33 & - & + & Montana \\
\hline Nigrospora oryzae, 8 & - & + & Montana \\
\hline N. oryzae, 20 & - & + & Montana \\
\hline N. oryzae, 25 & - & + & Montana \\
\hline Peyronellaea pinodella, 001 & - & + & Washington \\
\hline P. pinodella, 002 & - & + & Idaho \\
\hline P. pinodella, 003 & - & + & North Dakota \\
\hline P. pinodes, AP1 & - & + & Idaho \\
\hline P. pinodes, AP2 & - & + & Washington \\
\hline$P$. pinodes, $\mathrm{AP} 3$ & - & + & Montana \\
\hline Phoma koolunga, T040 & - & + & Australia \\
\hline P. koolunga, FT07013 & - & + & Australia \\
\hline P. koolunga, FT15012 & - & + & Australia \\
\hline Phoma sp., PH1 & - & + & Montana \\
\hline Phoma sp., PH2 & - & + & Montana \\
\hline Phoma sp., PHM & - & + & Montana \\
\hline Sclerotinia sclerotiorum, 36 & - & + & Montana \\
\hline S. sclerotiorum, 38 & - & + & Montana \\
\hline Stemphylium vesicarium, 12 & - & + & Montana \\
\hline S. vesicarium, 14 & - & + & Montana \\
\hline S. vesicarium, 41 & - & + & Montana \\
\hline No template & - & - & $\ldots$ \\
\hline
\end{tabular}

${ }^{\mathrm{a}}$ D. pisi-specific primers were used for the PCR amplification. ITS $=$ internal transcribed spacer.

Table 2. Primer pairs used for specific amplification of Didymella pisi, internal transcribed spacer (ITS), and Rubisco L-gene (RBCL)

\begin{tabular}{|c|c|c|c|c|c|}
\hline Primers & Primer sequence $\left(5^{\prime}-3^{\prime}\right)$ & Repeat motifs $^{\mathbf{a}}$ & Size (bp) & Reference & Purpose $^{\mathrm{b}}$ \\
\hline A311-F & AGCAGGCATTACGTTTAACT & $(\mathrm{AGC}) 6$ & 249 & Owati et al. 2019 & D. pisi \\
\hline A311-R & GGTAAGATGCGAGTACGAAT & $(\mathrm{AGC}) 6$ & 249 & Owati et al. 2019 & D. pisi \\
\hline A313-F & ATAACAACCAACCTCTGACG & $(\mathrm{ACC}) 6$ & 486 & Owati et al. 2019 & D. pisi \\
\hline A313-R & GGAGCAATAGGTGATCTTCTC & $(\mathrm{ACC}) 6$ & 486 & Owati et al. 2019 & D. pisi \\
\hline A315-F & GGTGGACTGAGTTCTGTGTAG & (TTC)7 & 199 & Owati et al. 2019 & D. pisi \\
\hline A315-R & TAGCGTGCTCTTGAGGATTA & (TTC)7 & 199 & Owati et al. 2019 & D. pisi \\
\hline A318-F & CTAGAATCGTGCTTGTTGC & (TCG)7 & 406 & Owati et al. 2019 & D. pisi \\
\hline A318-R & GAGTCTCCCTGTCTTTGTCC & (TCG)7 & 406 & Owati et al. 2019 & D. pisi \\
\hline ITS 1 & TCCGTAGGTGAACCTGCGG & NA & 550 & White et al. 1990 & Fungus \\
\hline ITS 4 & TCCTCCGCTTATTGATATGC & NA & 550 & White et al. 1990 & Fungus \\
\hline RBCL-H680 & TGGACTTGATTTTACCAAAGATGATG & NA & 642 & Nassuth et al. 2000 & Plant \\
\hline RBCL-C1321 & TGTCCTAAAGTTCCTCCACC & NA & 642 & Nassuth et al. 2000 & Plant \\
\hline
\end{tabular}

${ }^{\mathrm{a}} \mathrm{NA}=$ not applicable

${ }^{\mathrm{b}} D$. pisi $=D$. pisi amplification, Fungus $=$ internal control for fungi DNA, and Plant $=$ internal control for plant DNA. 
isolates at $50 \mathrm{ng}$ of DNA with a Cq value range of 19.53 to 20.73. Nontarget fungi species were not detected at 30 cycles (Table 3 ). The correlation coefficients for the standard curve of the DNAs from D. pisi pure cultures and conidial suspension were 0.999 and 0.980 , respectively (Table 5). The quantification limit for the qPCR was $0.01 \mathrm{ng}$ of mycelia DNA and 100 D. pisi conidia.

Validation of the SSR-qPCR assay. To validate the SSR-qPCR assay, DNA of 30 samples of $D$. pisi isolated from AB-contaminated seed lots mixed with $50 \mathrm{ng}$ of DNA of dry pea plants was evaluated. There was consistency in the sensitivity and specificity of the assay when compared with $\mathrm{Cq}$ values of pure culture. The mean $\mathrm{Cq}$ values of the samples tested ranged from 18.15 to 19.52 , with a standard deviation that ranged from 0.01 to 0.31 (Table 4 ).

\section{Discussion}

$\mathrm{AB}$ is a threat to dry pea production in the Great Plains of North America, Europe, and Australia (Ahmed et al. 2015; Chilvers et al. 2007; Davidson et al. 2009; Kaiser et al. 2008; Li et al. 2011; Tran et al. 2014). In Montana, D. pisi is the most prevalent fungal pathogen in the AB complex (Owati et al. 2017, 2019). Currently, rapid, specific, and sensitive molecular diagnostic assays for this pathogen are lacking. In this study, a rapid, specific, and sensitive qPCR assay was developed to specifically detect and quantify $D$. pisi using SSR primer pairs. In addition, conventional PCR assays were developed for use in laboratories without qPCR capabilities. Both methods specifically detected only $D$. pisi, not closely related fungal pathogens associated with $\mathrm{AB}$ complex of dry pea, other fungal pathogens

Table 4. SYBR Green real-time PCR validation of Didymella pisi-specific assay using genomic DNA of different fungal species associated with dry pea and genomic DNA of $D$. pisi isolates from Montana spiked with dry pea DNA samples

\begin{tabular}{|c|c|c|}
\hline Fungal species & Cq values $^{\mathbf{a}}$ & Standard deviation $^{b}$ \\
\hline \multicolumn{3}{|c|}{ Species associated with dry pea } \\
\hline Alternaria alternata & ND & nil \\
\hline A. alternata & ND & nil \\
\hline A. alternata & ND & nil \\
\hline Botrytis cinerea & ND & nil \\
\hline B. cinerea & ND & nil \\
\hline B. cinerea & ND & nil \\
\hline Cladosporium sp. & ND & nil \\
\hline Colletotrichum lentis & ND & nil \\
\hline C. lentis & ND & nil \\
\hline C. lentis & ND & nil \\
\hline Didymella pisi & 20.73 & 0.031 \\
\hline D. pisi & 20.37 & 0.021 \\
\hline D. pisi & 19.73 & 0.019 \\
\hline D. pisi & 19.50 & 0.022 \\
\hline Fusarium avenaceum & ND & nil \\
\hline F. avenaceum & ND & nil \\
\hline F. avenaceum & ND & nil \\
\hline Nigrospora oryzae & ND & nil \\
\hline$N$. oryzae & ND & nil \\
\hline N. oryzae & ND & nil \\
\hline Peyronellaea pinodella & ND & nil \\
\hline P. pinodella & ND & nil \\
\hline P. pinodella & ND & nil \\
\hline$P$. pinodes & ND & nil \\
\hline P. pinodes & ND & nil \\
\hline P. pinodes & ND & nil \\
\hline Phoma koolunga & ND & nil \\
\hline P. koolunga & ND & nil \\
\hline P. koolunga & ND & nil \\
\hline Phoma sp. & ND & nil \\
\hline Phoma sp. & ND & nil \\
\hline Phoma sp. & ND & nil \\
\hline & & (Continued) \\
\hline
\end{tabular}

${ }^{\mathrm{a}} \mathrm{Cq}=$ quantification cycle and $\mathrm{ND}=$ fluorescent signal not detected.

${ }^{\mathrm{b}}$ Based on two replicates. commonly found affecting dry pea, or host dry pea DNA. The assays were sensitive enough to detect $0.01 \mathrm{ng}$ of genomic $D$. pisi DNA of pure culture. In addition, the qPCR assay was sensitive enough to detect 100 conidia of $D$. pisi. This is four orders of magnitude less than the $10^{6}$ conidia/ml routinely used to cause infection in controlled experiments (Ahmed et al. 2015). This shows the robustness of our assay and suggests that it can be used to detect $D$. pisi from infected, non-symptomatic plants.

Various PCR and qPCR assays have been developed for the diagnosis of crop pathogens (Abdullah et al. 2018; Gramaje et al. 2013; Rojas et al. 2017; Wang et al. 2015; Zitnick-Anderson et al. 2018). Most of the qPCR- and PCR-based detection assays for plant pathogens were developed based on the intergenic sequences and ITS sequences of the ribosomal RNA (Bhat and Browne 2010; Rojas et al. 2017; Wang et al. 2015). This approach does not work well to differentiate closely related pathogens that share high sequence homology such as those associated with the $\mathrm{AB}$ complex of dry pea (Phan et al. 2002). The approach presented here, of designing the primers to flank loci of SSRs from contigs generated from Illumina next-generation sequencing reads, was instrumental to its high specificity and sensitivity. SSR loci are ubiquitous and offer a unique target in the fungal genome (Canfora et al. 2016; Owati et al. 2019). This characteristic makes SSR markers unique for the development of specific primers for pathogen detection. The specificity and sensitivity of our results are similar to the results of Canfora et al. (2016), who first reported the use of SSR primer-based qPCR for specific detection of fungal pathogens. The study developed an SSR-qPCR assay for the specific detection and quantification of Beauveria bassiana and B. brongniartii in culture and soil. To our knowledge, this study represents the first study where

Table 4. (Continued)

\begin{tabular}{|c|c|c|}
\hline Fungal species & Cq values ${ }^{\mathrm{a}}$ & Standard deviation ${ }^{\mathrm{b}}$ \\
\hline Sclerotinia sclerotiorum & ND & nil \\
\hline S. sclerotiorum & ND & nil \\
\hline Stemphylium vesicarium & ND & nil \\
\hline No-template control & ND & $\ldots$ \\
\hline \multicolumn{3}{|l|}{ Isolates from Montana } \\
\hline D. pisi-01 & 18.31 & 0.310 \\
\hline D. pisi-02 & 19.33 & 0.028 \\
\hline D. pisi-03 & 19.33 & 0.064 \\
\hline D. pisi-04 & 19.48 & 0.097 \\
\hline D. pisi-05 & 19.31 & 0.019 \\
\hline D. pisi-06 & 19.23 & 0.032 \\
\hline D. pisi-07 & 19.44 & 0.023 \\
\hline D. pisi-08 & 19.40 & 0.018 \\
\hline D. pisi-09 & 19.37 & 0.020 \\
\hline D. pisi-10 & 19.52 & 0.030 \\
\hline D. pisi-11 & 19.37 & 0.021 \\
\hline D. pisi-12 & 19.19 & 0.014 \\
\hline D. pisi-13 & 19.28 & 0.250 \\
\hline D. pisi-14 & 19.19 & 0.123 \\
\hline D. pisi-15 & 18.89 & 0.057 \\
\hline D. pisi-16 & 18.93 & 0.160 \\
\hline D. pisi-17 & 18.15 & 0.143 \\
\hline D. pisi- 18 & 19.34 & 0.013 \\
\hline D. pisi-19 & 19.36 & 0.018 \\
\hline D. pisi-20 & 19.46 & 0.041 \\
\hline D. pisi-21 & 19.35 & 0.095 \\
\hline D. pisi-22 & 19.47 & 0.044 \\
\hline D. pisi-23 & 19.18 & 0.127 \\
\hline D. pisi-24 & 19.39 & 0.031 \\
\hline D. pisi-25 & 19.36 & 0.174 \\
\hline D. pisi-26 & 19.45 & 0.092 \\
\hline D. pisi-27 & 19.28 & 0.101 \\
\hline D. pisi-28 & 19.04 & 0.154 \\
\hline D. pisi-29 & 19.28 & 0.186 \\
\hline D. pisi-30 & 19.16 & 0.027 \\
\hline No-template control & ND & $\ldots$ \\
\hline
\end{tabular}



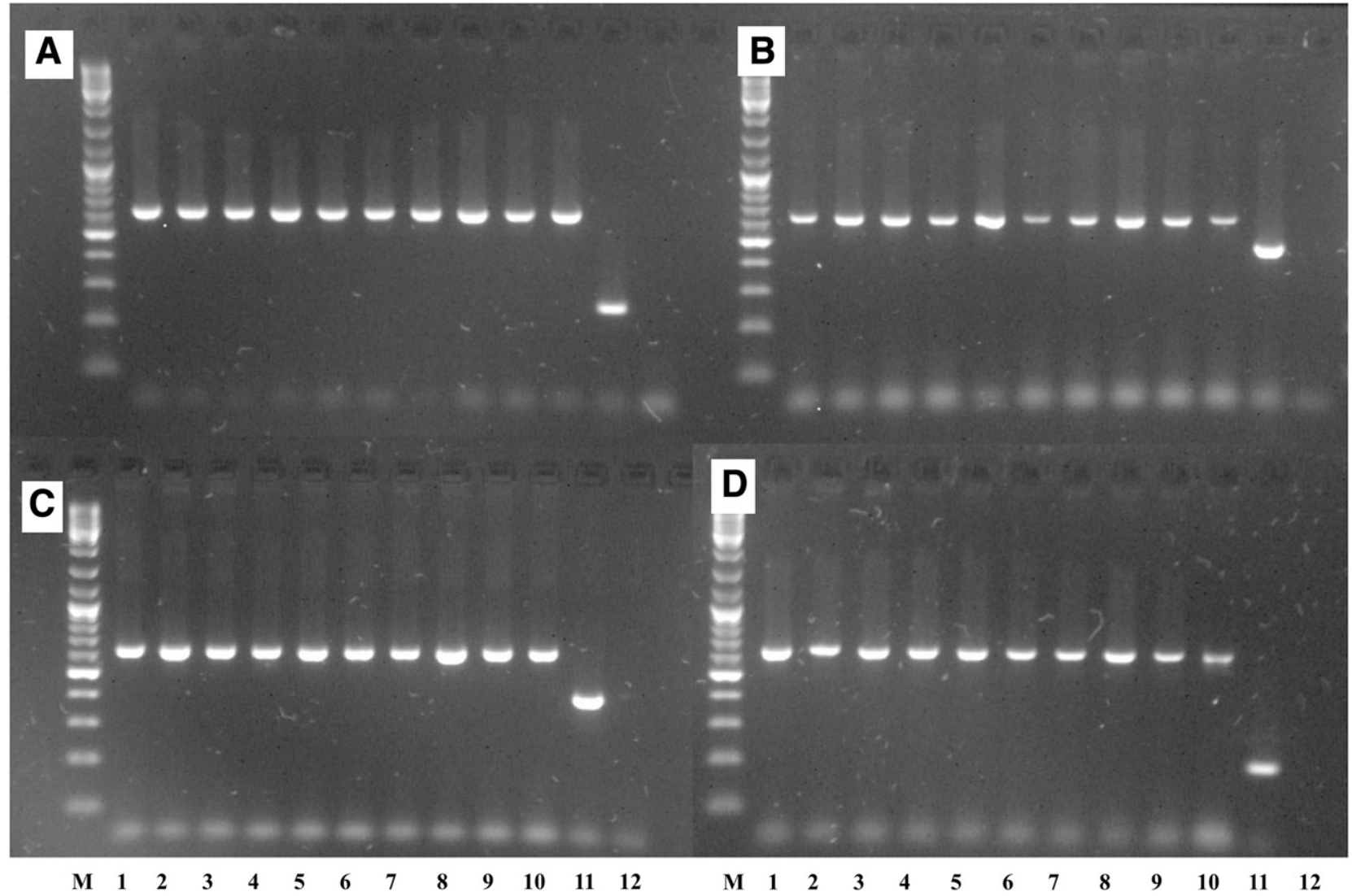

Fig. 1. Didymella pisi simple sequence repeat (SSR) primers specifically amplified D. pisi but not pea plant DNA in duplex PCR. A, Duplex PCR with A311 SSR primer and Rubisco L-gene (RBCL) primer pairs. B, Duplex PCR with A313 SSR primer and RBCL primer pairs. C, Duplex PCR with A318 SSR primer and RBCL primer pairs. D, Duplex PCR with A315 SSR primer and RBCL primer pairs. A311, A313, A318, and A315 are SSR primer pairs that specifically amplified 249-, 489-, 406-, and 199-bp products of D. pisi, respectively. RBCL primers amplified a 642-bp product from host plant DNA, serving as an internal PCR control. Lane M = 100-bp DNA ladder (100 to 1,500 bp), lanes 1 to $10=$ dry pea varieties (Hyline, Treasure, CDC Leroy, Banner, Aragorn, Ginny, Montech 4193, MSGA-Jet Set, Early Star, and Nette 2010, respectively), lane $11=D$. pisi DNA positive control, and lane $12=$ no template DNA.

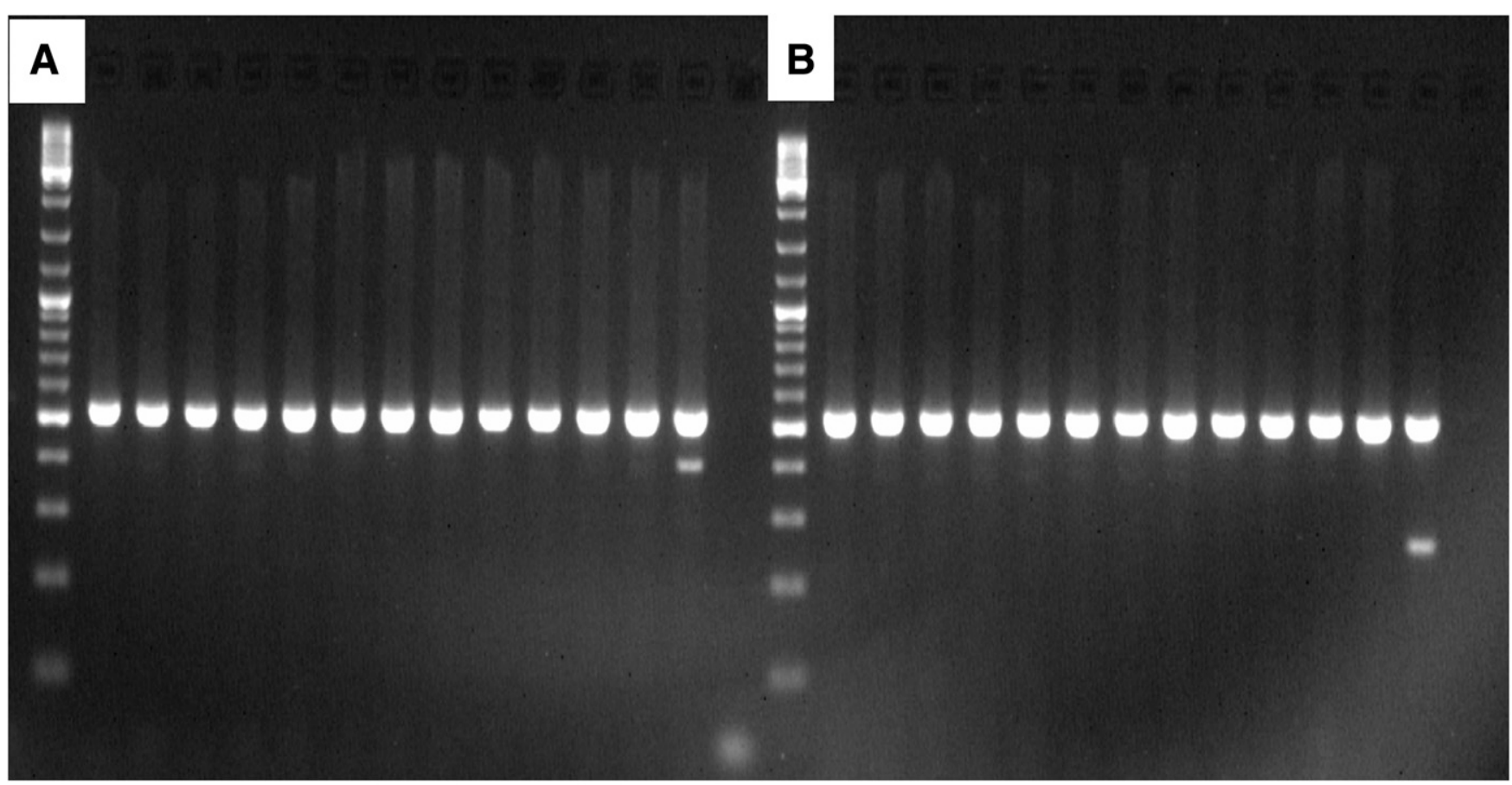

$\begin{array}{llllllllllllllllllllllllllllll}M & 1 & 2 & 3 & 4 & 5 & 6 & 7 & 8 & 9 & 10 & 11 & 12 & 13 & 14 & \text { M } & 1 & 2 & 3 & 4 & 5 & 6 & 7 & 8 & 9 & 10 & 11 & 12 & 13 & 14\end{array}$

Fig. 2. Didymella pisi simple sequence repeat (SSR)-primers specifically amplified D. pisi but not any other fungi in duplex PCR. A, Duplex PCR with A313 SSR and internal transcribed spacer (ITS)-1 and ITS-4 primer pairs. B, Duplex PCR with A311 SSR and ITS-1 and ITS-4 primer pairs. A311 and A313 are SSR primer pairs that specifically amplified 249- and 489-bp products of D. pisi, respectively. ITS-1 and ITS-4 generic primers amplified a 550-bp product of all the fungal DNA, serving as an internal fungal PCR control. Lane $M=100$-bp DNA ladder (100 to $1,500 \mathrm{bp}$ ), lanes 1 to $4=P$. pinodes isolates, lanes 5 to $8=P$. pinodella isolates, lanes 9 to $12=P h o m a$ sp. isolates, lane $13=D$. pisi DNA positive control, and lane $14=$ no template DNA. 
this novel approach was used to develop specific markers for the detection and quantification of a member of the $\mathrm{AB}$ complex in dry pea or $\mathrm{AB}$ causal pathogen in another pulse crop.

The need for consistent and accurate PCR-based diagnostic assays for the detection of plant pathogens cannot be overemphasized. The consequences of inaccurate diagnosis can range from the misinformed use of pesticides to hindrances in international trade. Some of the previously developed PCR and qPCR assays for the detection of plant pathogens lacked the inclusion of internal controls (Bonants et al. 1997; Bhat and Browne 2010; Cao et al. 2007; Chilvers et al.

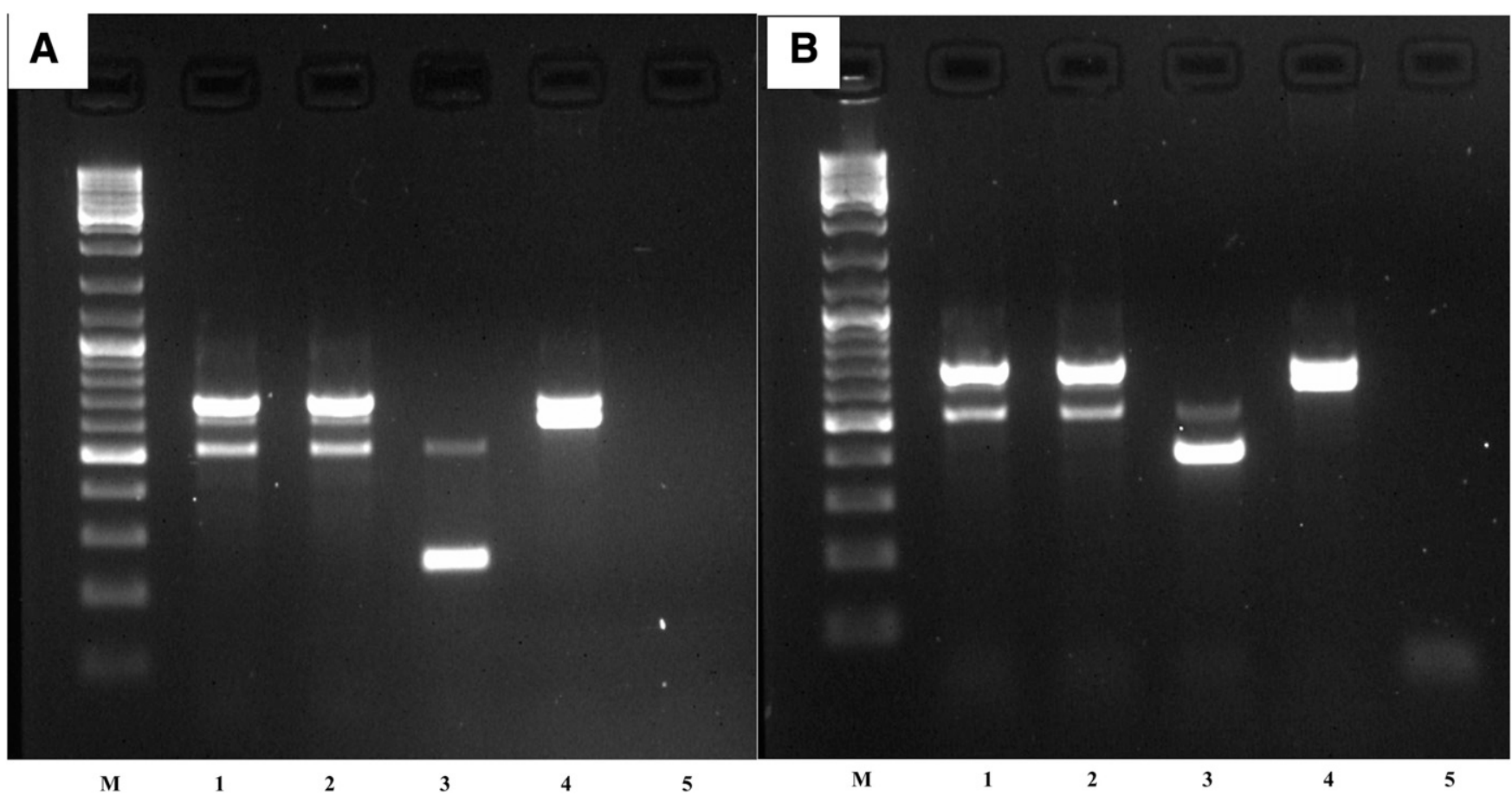

Fig. 3. Multiplex PCR detection of Didymella pisi, fungal internal transcribed spacer (ITS), and host plant Rubisco L-gene (RBCL). A, Multiplex PCR with A311 simple sequence repeat (SSR), ITS-1/ITS-4, and RBCL primer pairs. B, Multiplex PCR with A313 SSR, ITS-1/ITS-4, and RBCL primer pairs. Primer pairs A311 and A313 are SSR primer pairs that specifically amplified 249- and 489-bp products of $D$. pisi, respectively. ITS-1 and ITS-4 = generic primers that amplified 550-bp ITS product of any of the fungal DNA, serving as an internal fungal PCR control. Lane $\mathrm{M}=100$-bp DNA ladder (100 to 1,500 bp), lanes 1 and $2=$ dry pea leaf samples infected with Alternaria alternate, lane $3=D$. pisi DNA positive control, lane 4 = healthy dry pea leaf sample, and lane $5=$ no template.

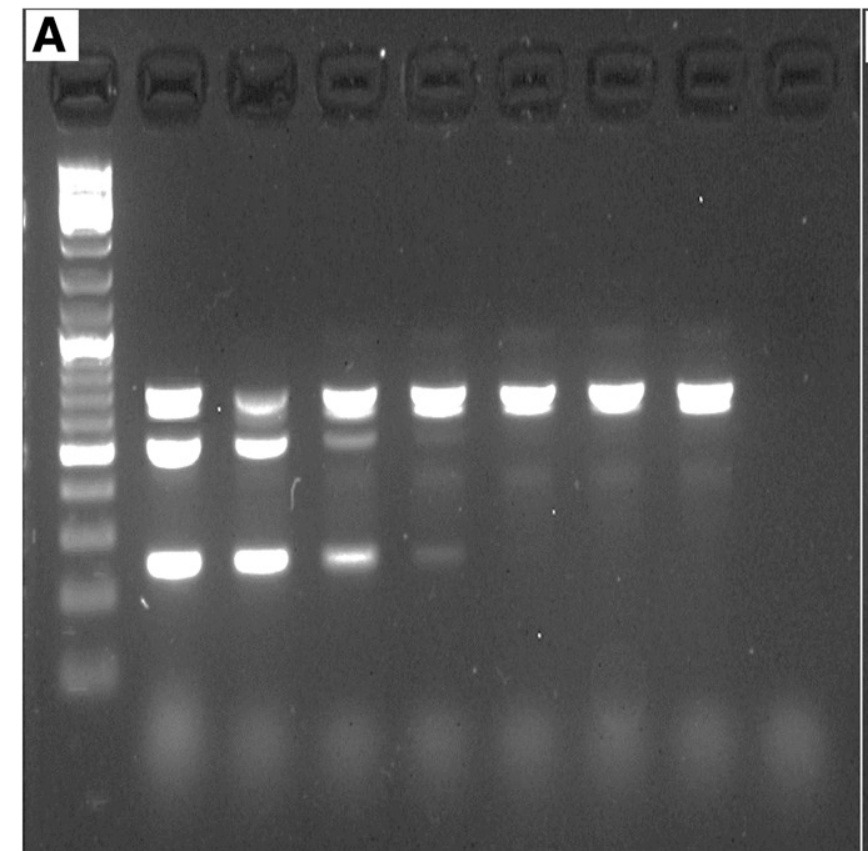

M 1 2 3 4 5 6 7 8 M

B

Fig. 4. Sensitivity of multiplex PCR detection of Didymella pisi in the presence and absence of host plant DNA. A, Multiplex PCR with A311, internal transcribed spacer (ITS)-1//TS4, and Rubisco L-gene (RBCL) primer pairs. Lane M =100-bp DNA ladder (100 to 1,500 bp), lanes 1 to 7, 10-fold serial dilution of D. pisi DNA from $100 \mathrm{ng}$ to $0.00001 \mathrm{ng}$ in $50 \mathrm{ng}$ of DNA of pea (Aragorn), and lane $8=$ no template. B, Duplex PCR with A311 and ITS-1 and ITS-4 primer pairs. Lane M = 100-bp DNA ladder (100 to 1,500 bp), lanes 1 to 7, 10 -fold serial dilution of $D$. pisi DNA from $100 \mathrm{ng}$ to $0.00001 \mathrm{ng}$. A311 and A313 are simple sequence repeat primer pairs that specifically amplified 249-and 489-bp products of $D$. pisi, respectively. ITS-1 and ITS-4 = generic primers that amplified 550-bp ITS product of any of the fungal DNA, serving as an internal fungal PCR control. 
Table 5. Efficiency of real-time PCR using Didymella pisi-specific primer on different sources of DNA

\begin{tabular}{lccccc}
\hline Sources of DNA & $\begin{array}{c}\text { Efficiency } \\
(\boldsymbol{\%})\end{array}$ & Slope & Intercept & $\boldsymbol{R}^{\mathbf{2}}$ & $\begin{array}{c}\text { Cq values } \\
(\mathbf{m i n}-\mathbf{m a x})^{\mathbf{a}}\end{array}$ \\
\hline $\begin{array}{c}\text { D. pisi pure } \\
\text { mycelial culture }\end{array}$ & 96.5 & -3.408 & 26.280 & 0.999 & $19.2-28.5$ \\
$\begin{array}{c}\text { D. pisi conidial } \\
\text { suspension }\end{array}$ & 115.6 & -2.996 & 32.433 & 0.980 & $17.5-29.7$ \\
\hline
\end{tabular}

${ }^{a}$ Minimum to maximum (min-max) linear range of quantification cycle $(\mathrm{Cq})$ values.

2007; Wang et al. 2006). Internal controls are essential in the assay to control for background amplification and prevent false-negative reports. Hence, our PCR-based assay was designed to multiplex the detection of $D$. pisi with those of ITS and RBCL, which are internal control targets of fungi and plants, respectively. This approach is consistent with other PCR and qPCR assays, where internal controls are included in the assays for the detection of Fusarium virguliforme, the causal agent of soybean sudden death syndrome, and Phytophthora sojae and $P$. sansomeana, root rot pathogens of soybean (Rojas et al. 2017; Wang et al. 2015).

The development of the assays presented here is timely. Montana shares local and international borders with North Dakota and Canada. The pathogen composition of $\mathrm{AB}$ complex of dry pea differs geographically. In North Dakota and Canada (Alberta, Saskatchewan, and Manitoba), the pathogen complex consists of Peyronellaea pinodes, $P$. pinodella, and rarely D. pisi (Ahmed et al. 2015; Chilvers et al. 2009; Gossen et al. 2011; Sivachandra-Kumar and Banniza 2017). The proximity of these regions and exchange of germplasm is anticipated to influence changes in population dynamics of the pathogen complex (Sivachandra-Kumar and Banniza 2017). The qPCR and PCR assays developed in this study allow for rapid, accurate identification and quantification of $D$. pisi. These tools will be used for epidemiological studies and monitoring changes in pathogen composition. These assays may be used to screen for $A B$ resistance in dry pea, where visual estimation or culture-based methods are difficult or not practical. In addition, the assays can be used to rapidly screen fungal spore traps to understand the distribution of the pathogen and inform the choice of disease management strategy. Furthermore, these assays present an important tool for monitoring changes in the pathogen population. This concern is heightened because the fungal pathogens associated with $\mathrm{AB}$ of dry pea in Canada and North Dakota were reported to be more aggressive than D. pisi (Kraft et al. 1998). Also, populations of $P$. pinodes are at a risk to develop insensitivity to frequently used fungicides such as quinone outside inhibitor fungicides (Gossen et al. 2014). This type of information will inform improvement on AB management strategies in Montana's dry pea fields. Finally, the $D$. pisi-specific primers could potentially be multiplexed with specific primers for other members of the complex.

\section{Literature Cited}

Abarshi, M. M., Mohammed, I. U., Wasswa, P., Hillocks, R. J., Holt, J., Legg, J. P., Seal, S. E., and Maruthi, M. N. 2010. Optimization of diagnostic RT-PCR protocols and sampling procedures for the reliable and cost-effective detection of Cassava brown streak virus. J. Virol. Methods 163:353-359.

Abdullah, A. S., Turo, C., Moffat, C. S., Lopez-Ruiz, F. J., Gibberd, M. R., Hamblin, J., and Zerihun, A. 2018. Real-time PCR for diagnosing and quantifying co-infection by two globally distributed fungal pathogens of wheat. Front. Plant Sci. 9:1086.

Ahmed, H., Chang, K.-F., Hwang, S.-F., Fu, H., Zhou, Q., Strelkov, S., Conner, R., and Gossen, B. 2015. Morphological characterization of fungi associated with the Ascochyta blight complex and pathogenic variability of Mycosphaerella pinodes on field pea crops in central Alberta. Crop J. 3:10-18.

Aveskamp, M. M., de Gruyter, J., Woudenberg, J. H. C., Verkley, G. J. M., and Crous, P. W. 2010. Highlights of the didymellaceae: A polyphasic approach to characterise Phoma and related pleosporalean genera. Stud. Mycol. 65: $1-60$.

Barilli, E., Cobos, M. J., and Rubiales, D. 2016. Clarification on host range of Didymella pinodes the causal agent of pea Ascochyta blight. Front. Plant Sci. $7: 592$
Bhat, R. G., and Browne, G. T. 2010. Specific detection of Phytophthora cactorum in diseased strawberry plants using nested polymerase chain reaction. Plant Pathol. 59:121-129.

Bonants, P., Hagenaar-de Weerdt, M., Vam Gent-Pelzer, M., Lacourt, I., Cooke, D., and Duncan, J. 1997. Detection and identification of Phytophthora fragariae Hickman by the polymerase chain reaction. Eur. J. Plant Pathol. 103:345-355.

Bretag, T. W., Keane, P. J., and Price, T. V. 2006. The epidemiology and control of Ascochyta blight in field peas: A review. Aust. J. Agric. Res. 57:883-902.

Bretag, T. W., and Ramsey, M. D. 2001. Foliar diseases caused by fungi: Ascochyta spp. Pages 24-28 in: Compendium of Pea Diseases and Pests. J. M. Kraft and F. L. Pfleger, eds. American Phytopathological Society, St. Paul, MN, U.S.A.

Brody, J. R., and Kern, S. E. 2004. History and principles of conductive media for standard DNA electrophoresis. Anal. Biochem. 333:1-13.

Canfora, L., Malusà, E., Tkaczuk, C., Tartanus, M., Łabanowska, B. H., and Pinzari, F. 2016. Development of a method for detection and quantification of B. brongniartii and B. bassiana in soil. Sci. Rep. 6: Article 22933.

Cao, T., Tewari, J., and Strelkov, S. E. 2007. Molecular detection of Plasmodiophora brassicae, causal agent of clubroot of crucifers, in plant and soil. Plant Dis. 91:80-87.

Chilvers, M. I., du Toit, L. J., Akamatsu, H., and Peever, T. L. 2007. A real-time, quantitative PCR seed assay for Botrytis spp. that cause neck rot of onion. Plant Dis. 91:599-608.

Chilvers, M. I., Rogers, J. D., Dugan, F. M., Stewart, J. E., Chen, W., and Peever, T. L. 2009. Didymella pisi sp., the teleomorph of Ascochyta pisi. Mycol. Res. 113:391-400

Davidson, J. A., Hartley, D., Priest, M., Krysinska-Kaczmarek, M., Herdina, McKay, A., and Scott, E. S. 2009. A new species of Phoma causes Ascochyta blight symptoms on field peas (Pisum sativum) in South Australia. Mycologia 101:120-128.

Davidson, J. A., Krysinska-Kaczmarek, M., Wilmshurst, C. J., McKay, A., Herdina, M., and Scott, E. S. 2011. Distribution and survival of Ascochyta blight pathogens in field pea cropping soils of Australia. Plant Dis. 95: 1217-1223.

Gossen, B. D., Hwang, S. F., Conner, R. L., and Chang, K. F. 2011. Managing the Ascochyta blight complex on dry peas in western Canada Prairie. Prairie Soils Crops J. 4:135-141.

Gossen, B. D., Carisse, O., Kawchuk, L. M., Van Der Heyden, H., and McDonald, M. R. 2014. Recent changes in fungicide use and the fungicide insensitivity of plant pathogens in Canada. Can. J. Plant Pathol. 36:327-340.

Gramaje, D., Pérez-Serrano, V., Montes-Borrego, M., Navas-Cortés, J. A. Jiménez-Díaz, R. M., and Landa, B. B. 2013. A comparison of real-time PCR protocols for the quantitative monitoring of asymptomatic olive infections by Verticillium dahliae pathotypes. Phytopathology 103:1058-1068.

Henson, J. M., Goins, T., Grey, W., Mathre, D. E., and Elliott, M. L. 1993. Use of polymerase chain reaction to detect Gaeumannomyces graminis DNA in plants grown in artificially and naturally infested soil. Phytopathology 83:283-287.

Hughes, K. J. D., Inman, A. J., Beales, P. A., Cook, R. T. A., Fulton, C. E., and McReynolds, A. D. K. 1998. PCR-based detection of Phytophthora fragariae in raspberry and strawberry roots. Pages 687-692 in: Brighton Crop Prot. Conf. Pests Dis., Vol. 2, November 16-19, 1998, Brighton, UK.

Hussain, S., Lees, A. K., Duncan, J. M., and Cooke, D. E. L. 2005. Development of a species-specific and sensitive detection assay for Phytophthora infestans and its application for monitoring of inoculum in tubers and soil. Plant Pathol. 54: 373-382.

International Seed Testing Association. 2017. Validated Seed Health Testing Methods. 7-005: Detection of Ascochyta pisi in Pisum sativum (pea) seed. https://www.seedtest.org/upload/cms/user/2017-SH-7-005.pdf

Kaiser, W. J., Viruega, J. R., Peever, T. L., and Trapero, A. 2008. First report of Ascochyta blight outbreak of pea caused by Ascochyta pisi in Spain. Plan Dis. 92:1365.

Keller, K. O., Engely, B., and Heinrich, K. 1995. Specific detection of Gaeumannomyces graminis in soil using polymerase chain reaction. Mycol. Res. 99:1385-1390.

Kraft, J. M., Larsen, R. C., and Inglis, D. A. 1998. Diseases of pea. Pages 325-363 in: The Pathology of Food and Pasture Legumes. D. J. Allen and J. M. Lenné, eds. CAB International, Wallingford, UK

Kuzdraliński, A., Kot, A., Szczerba, H., Ostrowska, A., Nowak, M., Muszyńska, M., Lechowski, M., and Muzyka, P. 2017. Novel PCR assays for the detection of biological agents responsible for wheat rust diseases: Puccinia triticina and Puccinia striiformis f. sp. tritici. J. Mol. Microbiol. Biotechnol. 27: 299-305.

Li, M., Inada, M., Watanabe, H., Suga, H., and Kageyama, K. 2013. Simultaneous Detection and Quantification of Phytophthora nicotianae and P. cactorum, and distribution analyses in strawberry greenhouses by duplex real-time PCR. Microbes Environ. 28:195-203.

Li, Y. P., You, M. P., Khan, T. N., Finnegan, P. M., and Barbetti, M. J. 2011. First report of Phoma herbarum on dry peas (Pisum sativum) in Australia. Plant Dis. 95:1590.

Lin, Y.-H., Chang, J.-Y., Liu, E.-T., Chao, C.-P., Huang, J.-W., and Chang, P.-F. L. 2009. Development of a molecular marker for specific detection of Fusarium oxysporum f. sp. cubense race 4. Eur. J. Plant Pathol. 123:353. 
Liu, N., Xu, S., Yao, X., Zhang, G., Mao, W., Hu, Q., Feng, Z., and Gong, Y. 2016. Studies on the control of Ascochyta blight in field peas (Pisum sativum L.) caused by Ascochyta pinodes in Zhejiang Province, China. Front. Microbiol. 7:481.

Moricca, S., Ragazzi, A., Kasuga, T., and Mitchelson, K. R. 1998. Detection of Fusarium oxysporum f. sp. vasinfectum in cotton tissue by polymerase chain reaction. Plant Pathol. 47:486-494.

Moukhamedov, R., Hu, X., Nazar, R. N., and Robb, J. 1994. Use of polymerase chain reaction-amplified ribosomal intergenic sequences for the diagnosis of Verticillium tricorpus. Phytopathology 84:256-259.

Nassuth, A., Pollari, E., Helmeczy, K., Stewart, S., and Kofalvi, S. A. 2000. Improved RNA extraction and one-tube RT-PCR assay for simultaneous detection of control plant RNA plus several viruses in plant extracts. J. Virol. Methods 90:37-49.

Niepold, F., and Schöber-Butin, B. 1995. Application of the PCR technique to detect Phytophthora infestans in potato tubers and leaves. Microbiol. Res. 150:379-385.

Owati, A. S., Agindotan, B., and Burrows, M. 2019. First microsatellite markers developed and applied for the genetic diversity study and population structure of Didymella pisi associated with Ascochyta blight of dry pea in Montana. Fungal Biol. 123:384-392.

Owati, A. S., Agindotan, B., Pasche, J. S., and Burrows, M. 2017. The detection and characterization of QoI-resistant Didymella rabiei causing Ascochyta blight of chickpea in Montana. Front. Plant Sci. 8:1165.

Phan, H. T. T., Ford, R., Bretag, T., and Taylor, P. W. J. 2002. A rapid and sensitive polymerase chain reaction (PCR) assay for detection of Ascochyta rabiei, the cause of Ascochyta blight of chickpea. Australas. Plant Pathol. 31:31-39.

Rojas, J. A., Miles, T. D., Coffey, M. D., Martin, F. N., and Chilvers, M. I. 2017. Development and application of qPCR and RPA genus- and species-specific detection of Phytophthora sojae and P. sansomeana root rot pathogens of soybean. Plant Dis. 101:1171-1181.

Sivachandra Kumar, N. T., and Banniza, S. 2017. Assessment of the effect of seed infection with Ascochyta pisi on pea in Western Canada. Front. Plant Sci. 8:933.

Skoglund, L. G., Harveson, R. M., Chen, W., Dugan, F., Schwartz, H. F., Markell, S. G., Porter, L., Burrows, M. L., and Goswami, R. 2011. Ascochyta blight of peas. Plant Health Prog. doi:10.1094/PHP-2011-0330-01-RS.
Tivoli, B., and Banniza, S. 2007. Comparison of the epidemiology of Ascochyta blights on grain legumes. Eur. J. Plant Pathol. 119:59-76.

Tran, H. S., You, M. P., Lanoiselet, V., Khan, T. N., and Barbetti, M. J. 2014. First report of Phoma glomerata associated with the Ascochyta blight complex on dry peas (Pisum sativum) in Australia. Plant Dis. 98:427.

USDA-NASS. 2017. United States Department of Agriculture-National Agricultural Statistics Service QuickStats. https:/quickstats.nass.usda.gov/

USDA-NASS. 2018. United States Department of Agriculture-National Agricultural Statistics Service QuickStats. https://quickstats.nass.usda.gov/

Wallen, V. R. 1965. Field evaluation and the importance of the Ascochyta complex on peas. Can. J. Plant Sci. 45:27-33.

Wang, J., Jacobs, J. L., Byrne, J. M., and Chilvers, M. I. 2015. Improved diagnoses and quantification of Fusarium virguliforme, causal agent of soybean sudden death syndrome. Phytopathology 105:378-387.

Wang, Y., Ren, Z., Zheng, X. B., and Wang, Y. C. 2007. Detection of Phytophthora melonis in samples of soil, water, and plant tissue with polymerase chain reaction. Can. J. Plant Pathol. 29:172-181.

Wang, Y., Zhang, W., Wang, Y., and Zheng, X. 2006. Rapid and sensitive detection of Phytophthora sojae in soil and infected soybeans by species-specific polymerase chain reaction assays. Phytopathology 96: 1315-1321.

White, T. J., Bruns, T., Lee, S., and Taylor, J. 1990. Amplification and direct sequencing of fungal ribosomal RNA genes for phylogenetics. Pages 315-322 in: PCR Protocols: A Guide to Methods and Applications. M. A. Innes, D. H. Gelfand, J. J. Sninsky, and T. J. White, eds. Academic Press, San Diego, CA, U.S.A.

Xue, A. G., Warkentin, T. D., and Kenaschuk, E. O. 1996. Mycosphaerella blight of field pea potential damage and fungicide control. Pages 5-6 in: Proc. Manitoba Agri-Forum, Winnipeg Manitoba, Canada.

Xue, A. G., Warkentin, T. D., and Kenaschuk, E. O. 1997. Effects of timings of inoculation with Mycosphaerella pinodes on yield and seed infection of field pea. Can. J. Plant Sci. 77:685-689.

Zitnick-Anderson, K., Simons, K., and Pasche, J. S. 2018. Detection and qPCR quantification of seven Fusarium species associated with the root rot complex in field pea. Can. J. Plant Pathol. 40:261-271. 